\title{
En homenaje a Graciela Hierro
}

Isabel Cabrera

\author{
Griselda Gutiérrez Castañeda, coord., \\ Graciela Hierro: in memoriam. México, UNAM, \\ Facultad de Filosofía y Letras, 2009. 238 pp.
}

$\mathrm{E}$

n nuestro medio, cuando por el pasillo vemos a alguien feliz y contento pensamos "pobrecillo, ya se le pasará", nada más se ponga a reflexionar y vea las cosas como realmente son, volverá la insatisfacción y las preocupaciones. Y en general, cuando oímos que alguien es mayoritariamente feliz pensamos que no reflexiona demasiado, o que es un tanto inconsciente; en pocas palabras: que para como están las cosas, sólo los tontos pueden decir que son felices. Creo que Graciela Hierro nos ha mostrado justo lo contrario, nos ha mostrado que para ser feliz hay que reflexionar, y que para conquistar la alegría hay que usar la inteligencia.

A pesar de ser una mujer elegante y mundana, la vida de Graciela no fue una vida fácil; simplemente insistir en contra de prejuicios atávicos -como el machismo o el patriarcado- en una época aún peor que la nuestra, no es hacerse la vida nada fácil; además, personalmente sufrió al menos dos rupturas amorosas importantes, aunque nunca se quedó en ellas, como el ave fénix se reconstruyó. Al final padeció una enfermedad terrible por contundente. No creo, pues, que hablemos de una mujer a la que la vida le regaló la felicidad. Su alegría y su bienestar eran su propia conquista.

Por eso es que la mayor parte de los textos que conforman este volumen -si no es que todos ellos- subrayan su cercanía, su alegría de vivir, su ironía, su vitalidad, su sabiduría, y en todo ello, su capacidad de aplicar la filosofía a su propia vida. Graciela Hierro creía que la ética tenía que servir para la vida, y antes que nada para hacernos más felices. Creo que el texto de Gloria Careaga la describe claramente: Graciela "concebía la filosofía [...] en su vínculo permanente con la vida concreta", y por ello la filosofía para ella "no era una ciencia abstracta sino un conocimiento vital". Esto no impide que Graciela Hierro tuviera sus filósofos clásicos predilectos; en mis conversaciones con ella-escasas pero sustanciosas- la oí mencionar a Aristóteles, Spinoza, Simone de Beauvoir (a quien ella convirtió en un clásico en este país) y a Stuart Mill. 
Y aunque nunca fui su alumna, por las conversaciones que tuvimos, y por los textos de la antología que hacen hincapié en su pensamiento moral, como el de Paulina Rivero, el de Carmen Trueba o el de Greta Rivara, puedo sintetizar algunas intuiciones que tenía ya sobre su concepción de la ética.

A Graciela Hierro le atraía la idea de Aristóteles de ligar la ética a la felicidad, así como su énfasis en el cultivo de virtudes a través de hábitos de vida, hábitos que ella a veces convertía en rutinas afortunadas, casi rituales, que afianzan lazos y recrean placeres. Carmen Silva dice que Graciela era muy sabia para disfrutar las pequeñas cosas y encontrar en los detalles de una situación, en esas nimiedades que pueden pasar desapercibidas, un motivo para alegrarse y sentirse agradecida. Por otro lado, creo que a Graciela Hierro le gustaba el tratamiento que hace Spinoza de las emociones, su análisis fino de situaciones posibles y su idea de concebir el bien como el estado donde predominan las pasiones alegres. Y junto con estos dos maestros, Graciela insiste en convertir la reflexión, y la búsqueda de la alegría y el placer en hábitos, en virtudes a cultivar a lo largo de su vida, cultivar el autoconocimiento, la decisión libre y autorresponsable, pero también cultivar el cuidado de una misma, y la alegría por la vida. Pero hay otra maestra central para Graciela, y es Simone de Beuavoir, de ella recoge la idea - nodal para su pensamiento-de que ninguna reflexión se hace "desde ningún lugar", todas se hacen desde quien uno es, y desde el género al que se pertenece.

Graciela se percató de que la ética feminista tenía, antes que nada, que construir una mirada propia, distinta de la mirada que le ha sido impuesta y desde la cual se nos identifica y se nos juzga como mujeres. Así habremos de labrarnos una identidad propia, y de esta manera, construir un lugar desde el cual reflexionar. Graciela creía -junto con Spinoza, pero sospecho que no a causa de él- que la ética está ligada al cuerpo, a las sensaciones, al dolor y al placer, y en el caso de la ética feminista, la reflexión parte desde un cuerpo femenino y, por consiguiente, debe consistir al menos en parte en una reivindicación del placer corporal, en conquistar la libertad sobre el placer propio. No es casual que muchos de los textos de esta antología citen su idea de que una vida sin reflexión no tiene sentido, y también citen, aunque casi nunca al mismo tiempo, su idea de que una vida sin placer no merece ser vivida. Recuerdo una ocasión que ante su insistencia en la importancia del placer, le dije que muchas veces el deber se opone al placer, ella me contra-objetó que la dicotomía placer/deber era una falsa dicotomía, y que a Griselda (Gutiérrez) y a mí nos había hecho daño "leer tanto a Kant".

Graciela Hierro hizo una síntesis peculiar y conformó una ética que valía para sí misma, que valía para ayudarle a vivir mejor, a convertirse en ese ser entrañable que caminó tantos años por estos pasillos. Ella enseñaba esta ética, pero su labor, tal como lo describen sus alumnos a lo largo del volumen, 
no era tanto la de transmitir información sobre diferentes autores, sino la de explicar a los autores en función de los casos a analizar. Graciela aterrizaba la reflexión en la experiencia vivida y ponía a prueba las ideas que estaban en los clásicos. Es por ello que Graciela Hierro lograba lo que pocos docentes logran: incidir en la vida de sus alumnos, ayudarles a conquistar sus primeras liberaciones y a encauzar su reflexión propia. Porque Graciela Hierro era una docente de tiempo completo, casi diríamos que no podía evitarlo, y durante muchos años su labor como maestra de la facultad fue central para su vida, y por ello dedicaba tiempo a conocer a sus alumnos, y en muchos casos, a construir una relación con ellos. Pero lo que buscaba no era su admiración, no buscaba que la siguieran, buscaba más bien decirles algo que les fuera útil para reflexionar y para liberarse de miedos. Pedro Joel dice que Graciela le enseñó que el maestro debe, no sólo gozar de la enseñanza, sino preparar al alumno para que pueda superarle, y cuando lo logra es que ha triunfado.

Y justamente porque Graciela Hierro buscaba una ética práctica que se pudiese aplicar a la vida, una ética que nos ayudara a ser más felices y, por consiguiente, a ser mejores personas, tuvo que enfrentarse no sólo con los atávicos prejuicios patriarcales que dominaban la academia, sino también con el descrédito que aún hoy día se le da en nuestro medio a la filosofía vista como una sabiduría vital, como una terapia que nos ayuda a vivir mejor. A veces es increíble cómo el desencanto, la oscuridad, y el discurso autorreferente tienen mucho mejor prensa en nuestro medio, que esta filosofía que se considera light. No se trata -como pretenden algunos- de concebir a la filosofía como un manual de autoayuda, sino de lograr que un pensamiento teórico y originalmente conceptual haga eco en nuestra vida práctica y cotidiana, y nos oriente. Porque ¿no acaso todos queremos aprender de nuestro oficio?, y en última instancia, ¿qué daño hace la convivencia de diferentes posturas frente a la filosofía?, ¿no ganamos todos con la diversidad de perspectivas? De cualquier manera, es curioso cómo nos hemos ido olvidando de este cultivo de uno mismo a través de la filosofía, que los griegos tanto enfatizaron y al que volvieron algunos ilustrados (me viene constantemente a la mente el sabio Hume). De cualquier manera, Graciela Hierro era el caso opuesto al filósofo solemne, cuya hondura se refleja en su carácter malhumorado y vanidoso, que usa un lenguaje obtuso y lleno de eruditas referencias que parece no tener nada que ver con la realidad. Graciela no tenía nada de esto, sus conversaciones eran profundas pero claras, profundas pero alegres, profundas pero esperanzadas.

Por último, señalo algo que admiraba especialmente de ella: Graciela, como Spinoza, nunca creyó que el sufrimiento trajera nada bueno, y miraba con harta desconfianza la tradición judeocristiana basada en la culpa y la redención. Parecía haberse liberado por completo del embrujo de una cultura centrada en el sacrificio y la compasión. Al respecto de una plática sobre estos temas 
en el coche -durante un trayecto a un restaurante en Insurgentes- me preguntó a bocajarro: ¿̨cuál crees tú que es la virtud más importante? Yo, que por entonces estaba pensando obsesivamente en la mística y el ascetismo, contesté, sin reflexionar demasiado: "la sencillez, la humildad". Me miró perpleja, un tanto horrorizada y me dijo "¿tú estudiaste con las monjas, verdad?" Era cierto, pero yo, a mi vez, me asombré de que alguien tan sencilla, no le diera importancia a la humildad.

Si nos preguntamos cuántas personas conocemos que saben ética en esta Facultad nos encontraremos un grupo numeroso, pero si nos preguntamos cuántas de esas personas han logrado ser más felices a través de la ética que enseñan, quizá el número se reduzca drásticamente. Por eso, muchas gracias Graciela por tratar de enseñarnos a vivir mejor. 